\title{
Considerações historiográficas sobre corporativismo, cidadania regulada e a história da assistência à saúde no Brasil: dádiva ou direito? (1930-1964)
}

\section{Historiographic considerations on corporatism, regulated citizenship and the history of health care in Brazil: gift or right? (1930-1964)}

\section{Consideraciones historiográficas sobre corporativismo, ciudadanía regulada e historia de La atención a la salud em Brasil: ¿dádiva o derecho? (1930-1964)}

\author{
José Roberto Franco Reis* \\ bttps: / orcid.org/0000-0002-1133-2778
}

RESUMO: De modo geral, os estudiosos da história da saúde observam uma cisão deste campo entre a assistência médica individual, dependente dos Institutos de Previdência (IAPs), criados nos anos 1930, e vinculados ao Ministério do Trabalho Indústria e Comércio (MTIC), e a saúde pública, dedicada, em geral, mas não só, às ações sanitárias contra epidemias e endemias que grassavam largamente no país, subordinada ao Ministério da Educação e Saúde Pública (MESP), criado à mesma época. Desta maneira, teríamos, de um lado, a saúde pública como fruto de iniciativas governamentais voltadas ao conjunto da população, com uma estrutura universalizada de serviços, não usufruído, porém, como um direito; e, de outro, a assistência médica individualizada, cuja inclusão, por intermédio da estrutura corporativista dos IAPs, apresentaria um caráter fragmentário, segmentado e seletivo, portanto, não universalista e não inclusivo, nos termos da chamada "cidadania regulada", de acordo com conceito cunhado pelo cientista político Wanderley Guilherme dos Santos. Nosso objetivo, neste artigo, é problematizar, à luz da literatura histórica mais recente, essa interpretação convencional do processo de estruturação da assistência à saúde no Brasil, que tende a caracterizá-la não como um processo de luta por direito de cidadania e sim como outorga ou dádiva governamental, conforme os objetivos políticos e ideológicos do primeiro Governo Vargas. Nesse sentido, pretendemos demonstrar como tanto a "cidadania regulada" quanto o "corporativismo" se constituíram, desde o início, em arranjos atravessados, em larga

\footnotetext{
* Pesquisador da Casa de Oswaldo Cruz (COC- FIOCRUZ), Doutor em História Social do Trabalho pela Universidade Estadual de Campinas (Unicamp). Autor ente ouros artigos de: "É o doutor que vem aí!': guardas sanitários, relações de trabalho e formação de identidade, 1930-1940 (Revista Brasileira de História, 2016); "Viver é influenciar": Mário Magalhaes, sanitarismo desenvolvimentista e campo intelectual da saúde pública, $194-1960$ (Tempo Social, 2015). Tem experiência na área de História, atuando nos seguintes temas: cultura de direitos, políticas sociais, história da cidadania, história da saúde e da psiquiatria. E-mail: jose.reis@fiocruz.br
} 
medida, por disputas e contradições que lhe conferiam certo grau de flexibilidade e permeabilidade para absorver as demandas por direitos oriundas do mundo do trabalho.

Palavras-chave: Corporativismo. Cidadania regulada. Assistência à saúde. História e historiografia da saúde.

ABSTRACT: In general, health history scholars observe a split in this field between individual medical assistance, dependent on the Social Security Institutes (IAPs), created in the 1930s, under the control of the Ministry of Labor, Industry and Commerce (MTIC), and the public health, dedicated, in general, but not only, to health actions against epidemics and endemic diseases that were widely spread in the country, subordinated to the Ministry of Education and Public Health (MESP), created at the same time. In this way, we would have, on the one hand, public health as the result of government initiatives aimed at the population as a whole, with a universalized structure of services, not enjoyed, however, as a right; and, on the other hand, individualized health care, whose inclusion, through the corporatism structure of the IAPs, would present a fragmentary, segmented and selective character, therefore, not universalist and non-inclusive, in terms of the socalled "regulated citizenship", according to a concept coined by political scientist Wanderley Guilherme dos Santos. Our objective, in this article, is to problematize, in the light of the most recent historical literature, this conventional interpretation of the structuring process of health care in Brazil, which tends to characterize it not as a process of struggle for citizenship rights but as government grant or gift, according to the political and ideological objectives of the first Vargas Government. In this sense, we intend to demonstrate how both "regulated citizenship" and "corporatism" were constituted, from the beginning, in arrangements crossed, to a large extent, by disputes and contradictions that gave it a certain degree of flexibility and permeability to absorb the demands for rights from the world of work.

Keywords: Corporatism. Regulated citizenship. Health care. Health history and historiography of health.

RESUMEN: En general, los estudiosos de la historia de la salud en Brasil registran una escisión de este campo. Por un lado, la asistencia médica individual, dependiente de los institutos de previdencia (IAPs) creados en 1930 y vinculados al Ministerio del Trabajo, Industria y Comercio (MTIC). Por otro, la salud pública, dedicada, en general (aunque no solamente), a implementar acciones sanitarias contra epidemias y endemias extendidas ampliamente en el país, y subordinada al Ministerio de Educación y Salud Pública (MESP), creado en la misma época. De este modo, tenemos, por un lado, la salud pública como fruto de iniciativas gubernamentales dirigidas al conjunto de la población, con una estructura universalizada de servicios - aunque no vista como un derecho. Del otro, la asistencia médica individualizada, cuya inclusión, por intermedio de la estructura corporativista de los IAPs, presentaría un carácter fragmentario, segmentado y selectivo, es decir, no universalista y no inclusivo - en concordancia con la llamada "ciudadanía regulada", concepto acuñado por el politólogo Wanderley Guilherme dos Santos. En este artículo, nuestro objetivo es el de problematizar, a la luz de la literatura histórica más reciente, esa interpretación 
convencional del proceso de estructuración de la asistencia a la salud en Brasil, que tiende a caracterizarla no como un proceso de lucha por un derecho de ciudadanía, sino como un regalo o dádiva gubernamental, de acuerdo con los objetivos políticos e ideológicos del primer Gobierno Vargas. En ese sentido, pretendemos demostrar cómo tanto la "ciudadanía regulada", así como el "corporativismo", se constituyeron, desde el inicio, en componendas, condicionadas, en gran medida, por disputas y contradicciones que lo dotaron de cierto grado de flexibilidad y permeabilidad para absorber las demandas por derechos oriundas del mundo del trabajo.

Palabras clave: Corporativismo. Ciudadanía regulada. Atención a la salud. Historia e historiografía de la salud.

\section{Como citar este artigo:}

Reis, José Roberto Franco. "Considerações historiográficas sobre corporativismo, cidadania regulada e a história da assistência à saúde no Brasil: dádiva ou direito? (1930-1964)". Locus: Revista de História, 26, n. 2 (2020): 407-433.

\section{Apresentação}

Desde os anos 1930, com a estruturação mais efetiva do sistema de previdência brasileiro que, de acordo com a literatura sobre o tema, para se ter assistência à saúde no Brasil era preciso se encontrar regularmente inscrito em algum dos Institutos de Aposentadorias e Pensões, os chamados IAPs criados neste período ou em alguma das Caixas de Aposentadorias e Pensões (CAPs) ainda vigentes. No entanto, para que isso ocorresse havia a necessidade de possuir algum vínculo de trabalho formal em alguma ocupação reconhecida por lei. Quem não cumprisse tais requisitos tinha que se valer da caridade, da assistência privada ou fazer uso de alguns serviços de saúde organizados pelo Estado, tais como centros e postos de saúde e higiene instalados em algumas regiões do Brasil, tendo em vista o interesse do governo Vargas em "garantir [sua] presença no interior do país", "contribuindo para o projeto de state building” em andamento (Fonseca 2007, 29-31). Estamos falando, nesse caso, de um universo expressivo de brasileiros, todos aqueles que se encontravam em atividades autônomas, serviços domésticos, ou sobrevivendo na informalidade, além do expressivo universo de trabalhadores do campo, num país caracterizadamente rural até os anos 1960.

Sendo assim, de um modo geral os estudiosos da história da saúde no Brasil observam uma cisão nesse campo, com a assistência médica individual dependente dos Institutos de Previdência vinculados ao Ministério do Trabalho Indústria e Comércio (MTIC), e a saúde pública dedicada em geral, mas não só, às ações sanitárias contra epidemias e endemias que grassavam largamente 
no país (doenças de massa), subordinada por sua vez ao Ministério da Educação e Saúde Pública (MESP), criado em 1930, depois Ministério da Saúde em 1953. Ou seja, teríamos, de um lado a saúde pública fruto de iniciativas governamentais e voltado à população em geral, "enorme, diversa e dispersa por todo o país", um bem coletivo a ser usufruído por todos sem restrição, com uma estrutura de "serviços universalizados", ainda que incipientes, conforme salienta Cristina Fonseca (2007, 17-52). De outro, a assistência médica cuja inclusão, via corporativismo e por intermédio dos Institutos de Aposentadoria e Pensões (IAPs) dos anos 1930, apresentaria um caráter fragmentário, segmentado e seletivo, portanto, não universalista e não inclusivo, nos termos da chamada "cidadania regulada", de acordo com o conceito já consagrado de Wanderley Guilherme dos Santos $(1979,75)^{1}$, ou da lógica do "só quem tem ofício tem beneficio" assinalado por Angela de Castro Gomes $(1988,194)$. Nesse último caso, o que se veria estabelecido no âmbito da assistência à saúde por intermédio da cultura política trabalhista brasileira, de forte viés corporativista, de acordo com importantes autores, não seria uma cultura de direitos solidária, universalista e sim uma cultura de direitos muito peculiar que transmudaria a ideia de direito em privilégio, privilégio daqueles que possuíam carteira de trabalho assinada e que portanto estariam inseridos no mercado formal de trabalho.

Nesse sentido, o que se configuraria como característica geral da política de saúde no pós 1930, seria o caráter coletivo da saúde pública em contraposição à assistência médica individual oferecida pela previdência, o qual expressaria, no limite, a ideia de que apenas os problemas de saúde que ameaçassem a coletividade seriam reconhecidos como responsabilidade do poder público. Vale notar, entretanto, conforme mostra Fonseca no seu valioso estudo sobre o tema, que a prestação de serviços de saúde pública nos anos Vargas combinava “de forma peculiar a medicina preventiva e a chamada medicina curativa, delegando a cada uma um papel específico" $(2007,48)^{2}$.

\footnotetext{
${ }^{1} \mathrm{Na}$ sua análise sobre o processo de constituição de uma "cidadania regulada" ao longo dos anos 1930, Santos mostra que no Brasil a cidadania não se caracterizaria pela inscrição dos indivíduos em um código de valores políticos em que ser membro da comunidade seria suficiente e sim pela inserção em alguma ocupação reconhecida e definida em lei, o que tornava a carteira de trabalho mais do que uma evidência trabalhista, um atestado de pertencimento cívico: "A cidadania está embutida na profissão e os direitos do cidadão restringem-se aos direitos do lugar que ocupa no processo produtivo, tal como reconhecido por lei. Tornam-se pré-cidadãos, assim, todos aqueles cuja ocupação a lei desconhece (...) seria pré-cidadãos todos os trabalhadores da área rural(...) assim como seriam pré-cidadãos os trabalhadores urbanos (...) cujas ocupações não tenham sido reguladas por lei (...) a regulamentação das profissões, a carteira profissional e o sindicato público definem, assim, os três parâmetros no interior dos quais passa a se definir a cidadania" (Santos 1979, 75).

2 Nesse sentido, Fonseca contesta a declaração do ministro Gustavo Capanema de que "à saúde pública não interessa[ria] o caso individual”, que "o caso individual só interessa[ria] à saúde pública se pude[sse] afetar a coletividade, se fo[sse] capaz de pôr a coletividade em perigo", aliás uma das importantes contribuições do seu trabalho. (2007, 47-48). Com efeito, ela procura mostrar como diante das condições de saúde da maioria da população brasileira, o próprio sanitarista Barros Barreto figura mais importante à frente da saúde pública durante a gestão de Capanema no MESP, igualmente refratário à necessidade de conciliar saúde pública e assistência médica - reconhece que "provavelmente terá [o médico] também de fazer um pouco de assistência médica", não havendo como "em muitas regiões do pais (...) fugir [desse] consórcio” (2007, 194).
} 
Interpretação que, de certo modo, traz um elemento novo ao que frequentemente se diz sobre a saúde no período, ancorada em geral na clivagem apontada há pouco entre uma assistência médica individualizada como atribuição exclusiva dos institutos de previdência localizados no MTIC, e ações preventivas de combate às endemias e epidemias, ou seja, de saúde pública, atribuição do MESP. No entanto, tal não significa dizer que a perspectiva de implantação no MESP de uma estrutura de serviços de saúde universalizados, bem coletivo a ser usufruído por todos sem restrição envolvendo medicina preventiva e curativa, como já dito, compreendesse qualquer noção de direito social, antes, como salienta Fonseca, era "oferecido pelo Estado e dependia unicamente de sua iniciativa, de sua 'dádiva' e das negociações políticas que remetessem a seus interesses” (2007, 57).

Nosso objetivo neste artigo, então, se propõe a problematizar o processo de estruturação da assistência à saúde no Brasil entre os anos 1930 - 1964 que, de um modo geral, aparece não como um direito de cidadania, fruto de certa mobilização e reivindicação social e sim como outorga ou dádiva governamental, tendo em vista os objetivos políticos e ideológicos do Governo Vargas, afiançador inicial e principal de tal processo ${ }^{3}$. Mesmo considerando a intepretação inovadora de Fonseca sobre a saúde pública como "um bem coletivo, de dimensão essencialmente universal", permanece o fato de que tal bem coletivo - de modo até mais acentuado em termos de concessão ou benesse estatal ao que ocorreria no âmbito previdenciário ${ }^{4}$ - não era identificado como um direito social nem decorreria da luta de grupos de interesse organizados que reivindicassem acesso à saúde, visto, pois, como exclusiva iniciativa governamental, o que demonstraria "que a noção de direito e a universalização [seriam] questões independentes” (Fonseca 2007, 262). Sendo assim, nossa perspectiva neste estudo busca, à luz da literatura histórica mais recente, justamente problematizar o processo de estruturação da assistência à saúde no Brasil como exclusiva outorga ou dádiva governamental, porquanto observa tanto a cidadania regulada quanto a estrutura corporativista como arranjos em boa medida abertos ao conflito, vale dizer, com certa flexibilidade e capacidade para absorver formulações em alguma medida permeáveis às demandas e lutas por direitos oriundas do mundo do trabalho, bem como potencialmente abertas a objetivos mais universalistas em termos de acesso aos benefícios e serviços sociais.

Por fim, uma explicação rápida sobre o recorte cronológico desse estudo, que pretende se ater, como dissemos, aos anos entre 1930-1964. Consideramos que esse período se justifica pelo

\footnotetext{
${ }^{3}$ Em torno da saúde pública, o interesse era "garantir a presença no interior do país" no processo de construção e afirmação do Estado. Já no âmbito da assistência médica previdenciária - função dos IAPs e CAPs integrados à lógica corporativa das relações de trabalho - tratava-se de obter aquiescência e apaziguamento social na chave da colaboração e conciliação de classes.

$4 \mathrm{O}$ acesso aos benefícios previdenciários, saúde incluída, pelo menos eram reconhecidos como um direito social, embora referidos como outorgados pelo Estado.
} 
fato de ter sido no pós 1930, com consequências incontestes nos anos que se seguiram de 1945 a 1964 (e de certo modo até os dias atuais), que tomou forma a cultura política trabalhista de direitos no Brasil, caracterizada pelo sistema corporativista de relações de trabalho e por arranjos sociais de proteção e assistência assentados na referida e sempre citada cidadania regulada, ambos objetos centrais de nossa inquirição. Ademais, especificamente em relação à assistência médica no âmbito dos IAPS, tal marco cronológico se justifica porquanto foi a partir dos anos pós 1930 que se estabeleceu o sistema nacional de previdência social, com desdobramentos e mudanças incrementais importantes nos anos da experiência democrática de 1945-64. Mudanças ou propostas de mudança que de alguma maneira se prestam a questionar as ditas limitações no alcance dos serviços previdenciários no sentido de apontar para certa universalização, isto é, para a expansão do acesso aos benefícios e serviços sociais, notadamente os de saúde.

\section{Assistência à saúde e cidadania: entre o direito a dádiva}

No seu instigante estudo sobre a saúde nos anos do primeiro Governo Vargas, Fonseca ${ }^{5}$ considera que três aspectos marcaram o desenho institucional das ações de saúde pública do MESP: A) perfil da clientela; B) ênfase nas ações preventivas; C) caráter nacional do serviço. No primeiro caso, perfil da clientela, expressaria uma atuação ampla, "sem grupos definidos de demanda" e "direcionadas para a população com um todo", decorrendo, segundo a autora de

iniciativas governamentais em um processo de decisão política que envolveria mais diretamente a negociação entre os interesses dos representantes do governo central e aqueles identificados com os grupos locais de poder. A população civil, principal alvo das ações públicas não se encontrava presente como ator político (...) [No entanto], foi sua dimensão não restritiva, o fato de ter-se destinado à toda população indiscriminadamente, um dos importantes aspectos que caracterizaram a saúde pública, habilitando-a na direção de serviços universalizados (Fonseca 2007, 48-49).

Com relação à ênfase na prevenção, em certa medida seguiria as formulações dos anos 1910-1920 em torno do saneamento dos sertões (cuidado com a saúde do homem do campo e de combate às endemias rurais). No entanto, depois de um momento inicial de redução de gastos (com a diminuição da contribuição federal aos serviços de profilaxia rural existentes nos estados) amplia o seu leque de abrangência, tendo em vista as especificidades e a amplitude de atuação do MESP (serviços universalizados), que se dirigia à população não contemplada pelo sistema previdenciário (os outros cidadãos), com medidas preventivas voltadas ao controle e combate de doenças com perfil epidêmico, mas também dirigidas, com certa particularidade e de modo

\footnotetext{
${ }^{5} \mathrm{O}$ desenho institucional da saúde pública aqui esboçado acompanhará as formulações elencadas por Cristina Fonseca no seu importante trabalho (2001).
} 
esporádico, não prioritário, à assistência médica daqueles não cobertos pela assistência médica no âmbito dos IAPs.

Por fim, a atuação em âmbito nacional, expressaria o desafio de atender uma população enorme, diversa e dispersa por todo o país, "excluída do raio de ação dos organismos previdenciários", portanto numa perspectiva mais universal e não-restritiva, o que demandava uma estrutura que garantisse a presença do governo central nas regiões mais remotas do país" (Fonseca 2007, 52). Ou seja, exigia a presença do Estado em todo o território nacional, bem como a articulação político/administrativa entre o poder central e os estados, obtido isso através da "presença de representantes do governo federal nos estados e parcerias com os governos locais." (Fonseca 2007, p. 53)

Duas reformas importantes ocorreram na gestão Gustavo Capanema, ministro que conduziu a pasta da Educação e a Saúde Pública de 1934 a 1945. A reforma de 1937 (lei 378 de 13/01/1937), quando o MESP passa a se chamar Ministério da Educação e Saúde (MES) e estabelece o Departamento Nacional de Saúde (DNS) como órgão principal. Divide o território brasileiro em oito regiões, instituindo em cada região uma Delegacia Federal de Saúde ("olhos e mãos do DNS nos estados”), com o objetivo de ampliar, no âmbito da saúde pública, a presença do Estado no território brasileiro. (Fonseca 2007, 217). Além disso, institui as Conferências Nacionais de Saúde, com o propósito de "reunir periodicamente delegados de todos os estados num fórum nacional e de caráter oficial para discutir os temas da saúde pública” (Hochman 2001, 137).

E a reforma de 1941 (Decreto-lei 3.171 de 02/04/1941) que consolida a estrutura do DNS e institui os Serviços Nacionais em um total de doze - Lepra, Tuberculose, Febre Amarela, Malária, Peste, Doenças Mentais, Educação Sanitária, Fiscalização da Medicina, Câncer e Saúde dos Portos e mais o Serviço Federal de Bioestatística (SFB e o Serviço Federal de Águas e Esgotos (SFAE). Estabelece também uma redistribuição das Delegacias Federais de Saúde, com o objetivo de "fortalecer a ação federal em determinadas localidades do país, mantendo-se porém o mesmo número de regiões" (Fonseca 2007, 219).

Resumidamente, diante do que foi apresentado até agora, a saúde pública no primeiro Governo Vargas pode ser caracterizada por: (i) clientela ampla e não restritiva; (ii) caráter nacional; (iii) ênfase na prevenção; (iv) institucionalização de um sistema universal de saúde (pelo menos com tal pretensão); (v) configuração descolada da noção de direito social. De acordo com Fonseca,

como consequência, configurou-se no âmbito da saúde um serviço centralizado, paternalizado, desvinculado na noção de direito social e, portanto, sem designação formal de quem deveria assegurá-lo - já que a noção de direito pressupõe alguma instância responsável, a qual o usuário possa recorrer caso não consiga usufruir esse direito(...) A prestação de serviços públicos de saúde de forma abrangente, voltada para toda a população brasileira (...) [com] medidas de cunho universal [decorria do] do projeto de statebuilding 
que demandava um investimento neste setor social . Tal projeto demonstra, portanto, que a noção de direito e a universalização são questões independentes (Fonseca 2007, 262, grifo meu).

Assim, embora estabelecida entre 1930-1945, pode-se dizer que tal estrutura de saúde pública permanece, em suas linhas gerais, nos anos seguintes de 1945-19646. De acordo com Hochman, o período do primeiro Governo Vargas, pode ser considerado, “o marco mais definitivo no processo de construção institucional da saúde pública" quando se organizou e consolidou a "estrutura administrativa que permaneceu quase inalterada até a criação do Ministério da Saúde em 1953 e, de certo modo (...) até os anos 60" (2001, 135, grifo meu). De modo semelhante, para Fonseca, sobretudo com "as alterações institucionais definidas em 1941", se consagrou o “modelo de gestão em saúde pública que deixaria marcas nessa área durante décadas e do qual ainda somos herdeiros" (2007, 244, grifo meu).

Com efeito, apesar de ao longo dos anos 1945-1964 se verificar, como apontam Lima, Fonseca e Hochamn, uma vinculação crescente do tema da saúde aos "problemas do desenvolvimento e da pobreza”, ou seja, à crença na ideologia desenvolvimentista e no planejamento estatal como base para "superação da doença e do subdesenvolvimento" 7 , com o "deslocamento das discussões e do processo decisório para o legislativo e para a esfera política", num ambiente de "competição democrática" (eleições livres, liberdade de imprensa, demandas por direitos, disputas político-partidárias), do ponto de vista que interessa a este artigo, importa salientar que o "combate às endemias rurais e às doenças transmissíveis" mantém-se "como a principal preocupação dos organismos de saúde púbica (2005, 46-51). Sendo assim, apesar da intenção de alguns médicos e sanitaristas de incluir a "assistência médica na saúde pública", de "não estabelecer distinção entre ações curativas e preventivas" (aspecto que Fonseca já havia assinalado no período anterior de 1930-45), o que se observa é a "permanência da tensão" entre esses dois campos, com o "sistema assistencial vinculado ao circuito corporativo-previdenciário (no

\footnotetext{
${ }^{6}$ Segundo Lima, Fonseca e Hochman, os marcos centrais do período seriam: a criação do Ministério da Saúde em 1953, "velha aspiração dos médicos da saúde pública" mas que "não significou grandes mudanças nas estruturas institucionais"; a reorganização, pela Lei n. 2.743 de 6 de marco de 1956, dos Serviços Nacionais no Departamento Nacional de Endemias Rurais (DNERu); a campanha nacional contra a lepra; a campanha de erradicação e controle da malária; e a $3^{\text {a }}$ Conferência Nacional de Saúde em 1963 (2005, 50-51).

7 Embora inconteste no imaginário do período, em consonância com o "otimismo sanitário" do pós $2^{a}$ guerra, tal pressuposto desenvolvimentista, como salienta Reis, "não gerava um sentido único e uniforme", daí emergindo basicamente duas posições: por um lado, "os defensores da ideia de que a partir da implantação de uma moderna infraestrutura de saúde, de uma adequada educação sanitária e de mais conhecimentos e profissionais técnicos e qualificados" se resolveria os problemas sanitários, propiciando então desenvolvimento, prosperidade e superação da pobreza; por outro, os adeptos das teses do chamado sanitarismo desenvolvimentista, que propunham quase o inverso: "desenvolvimento, com prosperidade econômica e social, seria pré-condição para melhorias gerais nas condições de saúde". Assim, para os sanitaristas desenvolvimentistas, "investimentos excessivos em saúde, além de custosos, por si só não trariam resultados proporcionais em termos sanitários, ainda que ações médicas básicas possibilitassem condições mínimas indispensáveis para até mesmo inserir determinado país na rota do progresso e do desenvolvimento, este sim, prioritário e fundamental" (Reis 2015, 280).
} 
Ministério do Trabalho Indústria e Comércio, depois Ministério do Trabalho)", sem ser "objeto de propostas mais radicais de incorporação à saúde pública" $(2005,51)$.

Vejamos agora como tudo se passou no âmbito do MTIC e da assistência à saúde no sistema previdenciário. De acordo com Hochman e Fonseca, os IAPs instituídos no pós 1930 expressariam um rompimento com o padrão CAPs de organização do sistema de previdência, tendo em vista que englobariam "categorias profissionais em âmbito nacional", não mais por empresa, com forte mediação do poder estatal $(1999,77)$. Os institutos também apresentavam inovações no que diz respeito ao financiamento. Adotavam um modelo tripartite, com contribuição dos trabalhadores, dos patrões e também da União, que de forma direta (e não indireta como no caso das CAPs) devia contribuir com um valor que não podia ser inferior ao dos demais contribuintes (Fleury 2007, 91) ${ }^{8}$. Segundo boa parte dos estudiosos do tema, essas instituições foram criadas "de acordo com a lógica corporativista de relações de trabalho estabelecida pelo regime Vargas", que estimulava cada sindicato a entrar em contato direto com o Ministério do Trabalho para reivindicar um sistema de proteção previdenciário mais completo. Assim, "cada grupo recebia sua própria CAP ou IAP, e também sua lei específica", daí resultando uma "coleção espantosa de leis e normas operacionais e uma variedade de modelos diferentes de proteção e financiamento” (Malloy 1986, 76-77). Os IAPs seriam dirigidos "por um funcionário executivo (Presidente ou diretor), escolhido pelo presidente da República" e "assessorado por uma espécie de colegiado, com representação igual de empregados e empregadores da categoria, variando entre quatro e oito" (Malloy 1986, 77). O mais importante nesse caso, é que "os membros dos conselhos e juntas de trabalho eram sempre relacionados por representantes de sindicatos aprovados que se reuniam em assembleia convocada pelo Ministério do Trabalho", tornando o sistema de previdência social ligado ao sistema de sindicatos de trabalhadores (Malloy 1986, 77). Surgem, então, em 1933, o Instituto de Aposentadoria e Pensões dos Marítimos (IAPM) e, em 1934, o Instituto de Aposentadoria e Pensões dos Comerciários (IAPC) e o Instituto de Aposentadoria e Pensões dos Bancários (IAPB). Em 1937 é criado o Instituto dos Industriários (IAPI), e em 1938 são reorganizadas algumas caixas que dão origem ao Instituto de Aposentadoria e Pensões dos Estivadores (IAPE) e ao Instituto de Aposentadoria e Pensões dos Empregados em Transportes e Cargas (IAPTEC) (em 1945 o IAPE é incorporado ao IAPTEC). Ainda em 1938, englobando os funcionários públicos federais,

\footnotetext{
${ }^{8}$ Quanto ao caráter inovador ou não das políticas previdenciárias do pós 1930, segundo Hochman e Fonseca, existem posições distintas entre os estudiosos: a dos que defendem, como James Malloy, que a concepção básica de segmentação dos trabalhadores por categorias profissionais e o viés elitista e paternalista do modelo já estavam estabelecidos antes de 1930 e os que identificam uma ruptura no período Vargas, quando se tornam estatais os arranjos previdenciários, muito se diferenciando do modelo civil e privado das CAPs "sem ingerência estatal na provisão de benefícios e serviços' (Hochman e Fonseca 1999, 77).
} 
estrutura-se o Instituto de Previdência e Assistência dos Servidores do Estado (IPASE). Em 1953, através da reunião das últimas CAPs, é criado o IAP dos Ferroviários e Empregados em Serviços Públicos (IAPFESP)9. (Oliveira e Teixeira 1986; Malloy 1986; Hochman 2006; Santos 1979).

Sendo assim, pode-se dizer que entre os anos 1930-1938, as linhas gerais do sistema de previdência estavam definidas e implementadas, sendo "parte integrante de uma estratégia maior de política estatal iniciada pelo regime Vargas” (Malloy1986, 86). Com efeito, segundo Malloy, “por volta de 1939, o sistema básico estava constituído" com a existência de "noventa e oito CAPs e cinco IAPs, e uma população total assegurada de 1.838 .885 ativos e 81.142 não ativos” $(1986,75)$. Por sua vez, para Oliveira e Teixeira, se "nos sete anos compreendidos entre 1923 e 1930, o número de associados ativos crescera de seis vezes atingindo a marca de 140.000", no período de 1930 a 1945 este número aumentou quase 20 vezes, chegando ao final dele com a "cifra de 2.888.000 associados" (1986, 59). De acordo com Santos, em 1948 havia 30 CAPs e 6 IAPS, com "aproximadamente 3.000.000 de segurados ativos, 158.800 aposentados e 171.000 dependentes" $(1979,32)$. Em 1959, tendo por base o Anuário Estatístico do Brasil, Hochman aponta que os seis IAPS e mais o IPASE “totalizavam 4.200 milhões de associados, 482.428 aposentados e 604.427 pensionistas" (2006).

Em relação à prestação da assistência médica, segundo importantes autores do campo da saúde, até os anos 1950 pelo menos, tal serviço seria secundário nos IAPs e CAPs (apesar da permanente reivindicação dos trabalhadores e do crescimento dos gastos com saúde entre 19231949), em boa medida condicionado à disponibilidade de recursos (em alguns casos com uma cobrança adicional) e com teto máximo de gastos em boa parte deles (Menicucci 2007, 64-66; Vianna 2000, 141e 158; Braga e Paula 1981, 71-72). Além disso, seu alcance variava de instituto para instituto, a depender da maior capacidade de mobilização e pressão política de uma dada categoria de trabalhadores e seus respectivos sindicatos junto ao Estado. O IAPI, por exemplo, destinava aos gastos com saúde em 1964, 20.2\% do seu orçamento, enquanto o IAPB, o mais pródigo de todos, $63,4 \%$, "em razão da capacidade também maior de mobilização e pressão dos bancários”. (Menicucci 2007, 65-66; Vianna 2000, 141) ${ }^{10}$. Como apontam Braga e Paula (1981, 82), a partir de 1960 os institutos estavam submetidos a fortes pressões "no sentido de elevar seu gasto com assistência médica", entretanto o resultado disso teria sido distinto, a depender "basicamente

\footnotetext{
9 Observamos algumas diferenças de data ente os autores citados acima em relação à criação de alguns institutos, notadamente o IAPI (1936 ou 1937?) e o IAPFESP (1953 ou 1954?). Também em relação ao IAPFESP muitas vezes é dito que inicialmente ele se chamou CAPFESP.

${ }^{10}$ Uma medida importante foi a criação em 1949, do Serviço de Assistência Médica Domiciliar e de Urgência, o SAMDU, financiado por todos os IAPs e CAPs e que oferecia, como o próprio nome diz, atendimento médico domiciliar e de urgência aos segurados.
} 
da situação financeira de cada instituto e da força da pressão sindical” de cada categoria profissional, o que é revelador de como o acesso maior ou menor a serviços de saúde dependia muito da força de organização e reivindicação dos trabalhadores, sinalizando para um importante sentido de reconhecimento de direitos, ainda que amalgamado com a fórmula retórica da dádiva ou outorga, notadamente explorada pelo varguismo. De qualquer forma o decisivo aí, em termos da sua distinção com relação à saúde pública, é que para ter acesso à assistência médica era preciso se encontrar regularmente inscrito em uma CAP ou IAP. E para que isso acontecesse era necessário possuir algum vínculo de trabalho formalmente reconhecido, como já dito.

Aqui é possível apontar uma contradição importante para nossos propósitos: de um lado a saúde pública voltada à população em geral (inclusive a rural) sem discriminação, portanto um bem coletivo público de caráter abrangente e escopo universal, no entanto não demandado com um direito. Ainda que fosse uma reivindicação antiga de sanitaristas dos anos 1910-20, não resultou da luta de grupos de interesse organizados que reivindicassem acesso à saúde e sim da iniciativa do poder público de acordo com seus objetivos de expansão para o interior do país e de afirmação do Estado nacional. De outro, a medicina previdenciária, com seu caráter segmentado, seletivo, corporativo - não universal - voltado àqueles inseridos no mercado formal de trabalho (inscritos, nesse caso, em algum instituto ou Caixa) mas de algum modo reivindicada como um direito, ainda que nos marcos da cidadania regulada e construída pelo regime Vargas como uma dádiva ou benesse. Conforme assinala Fonseca:

Advogo que o modelo de atenção à saúde construído a partir da década de 1930 formalizou também a separação entre as noções de direito à saúde e seu usufruto. Neste campo a concepção da política social como outorga talvez tenha se dado de forma mais acentuada do que em outras esferas sociais. $\mathrm{Na}$ realidade, a noção de direito não parece estar embutida no usufruto desse bem coletivo - por quê? Por um lado porque - de acordo com a noção de cidadania regulada - a ideia do direito à saúde não era um bem inerente a qualquer cidadão. Ao distinguir, entre a população, os cidadãos e os précidadãos, aqueles que têm e os que não têm direito ao sistema previdenciário, e imprimir tal orientação à política social por meio da divisão entre os dois ministérios, o Estado não identifica os serviços prestados no âmbito da saúde pública como um direito. Este, enquanto tal, era reservado apenas aos cidadãos empregados no mercado formal de trabalho. Em contrapartida, as ações de saúde pública eram engendradas de forma unilateral, partiam diretamente de iniciativas governamentais, não foram fruto de negociações políticas nem de demandas entre uma clientela específica e o Estado. Em outras palavras, não havia reivindicação por saúde nem movimento associativo e organizacional em seu nome - este aspecto também contribui para o distanciamento da noção de direito (Fonseca 2007, 55).

Por sua vez para a socióloga Telma Menicucci, tratando especificamente da assistência médica previdenciária,

A expansão da assistência médica se deu a partir da segmentação entre os trabalhadores, objeto das políticas. A forma corporativa que caracterizou a criação e expansão da previdência social brasileira, e vinculada a ela a assistência à saúde de maior proporção, expressou como uma conquista ou uma concessão para grupos particulares de trabalhadores inseridos no mercado formal de trabalho. Dessa forma, na sua origem a assistência médica pública não se constitui em razão de objetivos 
universalistas e igualitários, e ao longo do tempo foram se desenvolvendo formas variadas de segmentação, que se traduziam na inserção em instituições de saúde diferentes. Uma das consequências desta segmentação institucional foi a ausência de uma efetiva solidariedade entre trabalhadores e de uma consciência de interdependência, de forma a construir uma coletividade. Isso vai se traduzir posteriormente na ausência de uma sustentação política efetiva, embora ela se desse formalmente, dos trabalhadores organizados a um sistema de saúde público universal" (Menicucci 2007, 59).

Corporativismo e universalismo, saúde pública e saúde previdenciária, cidadãos e précidadãos, inexistência de objetivos igualitários, distanciamento da noção de direito, outorga, conquista e/ou concessão, cidadania regulada, ausência de solidariedade e de consciência de interdependência, enfim, um conjunto amplo de formulações algumas vezes contrastantes mas que, ao fim e ao cabo, expressam uma interpretação em boa medida reificadora da noção de dádiva e desqualificadora da noção de direito social como possível conquista ou reivindicação. Com efeito, interessante observar como para boa parte das leituras sobre as políticas de saúde realizada por estudiosos do tema, a ênfase em certa característica da cultura de direitos do trabalho no Brasil informada seja pela cidadania regulada, seja pelo corporativismo, se apresenta como a principal responsável pela impossibilidade de uma extensão efetiva da cidadania, uma cidadania ampla que contemplasse todos os membros de uma dada comunidade política, elidindo a clivagem entre cidadãos (incluídos) e pré-cidadãos (excluídos). Nesse caso, a visão predominante nas interpretações corrobora a ideia de que uma determinada marca muito salientada do modelo de proteção social no Brasil, estabelecido nos anos 1930, na qual os trabalhadores teriam acesso diferenciado a certos direitos sociais diante de uma situação formal de inserção no mercado de trabalho, conformaria ao longo do tempo, "formas variadas de segmentação, que se traduziam na inserção em instituições de saúde diferentes" (Menicucci 2007, 59). Mesmo o importante e inovador estudo de Fonseca, que mostra como no campo da saúde pública havia a pretensão de atender a todos indiscriminadamente, "bem coletivo de dimensão essencialmente universal" envolvendo medicina preventiva e curativa, deixa claro que tal pretensão não caracterizava qualquer noção de direito social nem decorria da luta de grupos de interesse organizados que reivindicassem acesso à saúde. Como ela diz, "não era usufruído como um direito social e, portanto, permanecia desvinculado de qualquer grupo de demanda" (2007, 57). Resultava, pois, de exclusiva iniciativa governamental, tendo em vista o "projeto político-ideológico de construção nacional” do Estado brasileiro, "que incorporava em seus propósitos a prestação de serviços públicos de saúde de forma abrangente, voltado para toda a população brasileira" $(2007,262)$. Ou seja, embora “oferecido pelo Estado dependia unicamente de sua iniciativa, de sua 'dádiva' e das negociações políticas que remetessem a seus interesses" (2007, 57), o que a leva inclusive a concluir que "a noção de direito e a universalização" se apresentam como "questões independentes" (2007, 262). 
Interessante observar, aliás, como para boa parte dos estudiosos do campo da saúde, mesmo no caso do Sistema Único de Saúde (SUS) instituído através da Constituição de 1988 - em tese expressão de uma mudança decisiva no sentido de afirmar uma perspectiva de acesso igualitário e universal à saúde, portanto de cidadania plena - as dificuldades e entraves no seu funcionamento se relacionam em larga medida com a herança segmentada e corporativa da nossa cultura de direitos. Com efeito, o que de um modo geral tais estudiosos identificam seria a reposição, em outros termos - agora através de "demandas particularistas (...) vinculados ao contrato de trabalho e não à categoria profissional" (Meninucci 2007, 87) - da antiga clivagem e exclusão do sistema de saúde brasileiro que, como dito acima por Menicucci, desde sempre não teria se constituído "em razão de objetivos universalistas e igualitários", sendo marcado por "segmentação institucional", "ausência de solidariedade entre trabalhadores" e "consciência de interdependência" $(2007,59)$. Como sugere o sociólogo Nilson Costa,

a tensão entre uma agenda publicista e a organização de interesses é a problemática central e específica dos anos 80, embora a questão da diferenciação da assistência médica para a força de trabalho ativa não constitua uma novidade. Esta[ria] na própria gênese da cidadania social brasileira [leia-se cidadania regulada e corporativismo], que condicionou desde os anos 30, através do vínculo contributivo, o acesso a serviços de internação hospitalar e atendimento ambulatorial" (Costa 1996, 347).

Vejamos, pois, as considerações da própria Cristina Fonseca, nesse caso em um texto bastante recente. Se referindo às análises da trajetória histórica das políticas de saúde a partir da clivagem medicina de cunho previdenciário versus os que se valiam dos serviços de saúde no âmbito do MES, chama atenção para,

o processo de estratificação na prestação de assistência médica, que se consolida ao longo das décadas de 1920-40, principalmente com a participação das organizações previdenciárias. Este modelo de política pública de saúde implementado marcou de maneira decisiva as possibilidades de mudanças e a viabilização de um sistema de saúde universal nas décadas seguintes, deixando heranças até os dias de hoje, como bem demonstrou Menicucci (Fonseca, 2019, 425, grifo meu).

E o que diz a socióloga Telma Menicucci, que Fonseca menciona? A citação é longa, porém bastante esclarecedora:

A proposta de um sistema de saúde igualitário chocou-se com o legado histórico de uma sociedade marcada pela diferenciação e pela segmentação no próprio campo da atenção à saúde, no qual o processo de inclusão se deu pela incorporação de segmentos privilegiados dos trabalhadores assalariados (...) No caso brasileiro, a reforma sanitária foi de inspiração claramente solidarista e com pretensões transformadoras que extrapolavam o setor saúde. Entretanto, não se pode dizer que esses valores estavam generalizados tanto na elite governante como na sociedade organizada. Ao contrário, como herança de políticas anteriores, tinham se desenvolvido práticas e, consequentemente, valores pouco solidaristas, $e$ não se constituíra uma demanda de atenção universal entre os segmentos organizados dos trabalhadores. A origem da Previdência Social no país, na qual se inseriu a assistência médica, não foi o resultado da constituição prévia do sentimento de pertencimento a uma comunidade, mas sim uma forma de o governo getulista buscar apoio de setores até então excluídos do jogo político pela via da corporativização das demandas dos trabalhadores. A história do alargamento dos benefícios previdenciários, entre eles a assistência médica, é também uma história de pressões dos trabalhadores 
mais organizados no sentido de obter ganhos diferenciados para cada categoria, situação propiciada pela própria configuração institucional da Previdência Social (...) Conquistas ou concessões de beneficios sociais diferenciados faziam parte do jogo político e eram usadas como moeda de troca, não tendo se constituído em um projeto de cidadania inclusiva. Essa origem da assistência calcada na diferenciação, primeiro no âmbito da assistência pública por meio dos IAPs e posteriormente em razão da distinção entre trabalhadores cobertos por planos empresariais e cobertos pela assistência pública, não favoreceu a constituição de uma identidade coletiva e de valores que enfatizassem a solidariedade e o igualitarismo que pudessem dar suporte à reforma (2007, 202-203, grifo meu).

Considero que aqui temos uma questão importante e creio que vale acompanhar o que os historiadores e alguns sociólogos têm dito já há algum tempo tanto sobre a questão da cidadania regulada quanto sobre o corporativismo. Adalberto Cardoso, por exemplo, no livro a Sociedade do Trabalho no Brasil, sugere que a cidadania regulada foi a forma possível da consciência de classe no Brasil, a "consciência do direito a seus direitos" (2010, 236), na medida em que "ofereceu um referencial poderoso para a construção de (...) identidades individuais e coletivas", porquanto “estava ao alcance de todos, desde que cada um se habilitasse a ela" (2010, 237). Uma espécie de promessa integradora que pautou o próprio "horizonte da luta de classes no Brasil" "pela qual passou a valer a pena lutar" (2010, 223- 224). Luta, nesse caso, marcada tanto pela constante ampliação desses direitos quanto pela implantação efetiva dos direitos estabelecidos, tendo em vista que por constarem da lei tais direitos não estavam exatamente garantidos. Mas também, e aqui um aspecto importante, luta pela extensão dos que podiam ser incluídos nessa nova formulação de direitos, isto é, pela introdução de novas categorias de trabalhadores no universo da cidadania regulada, o que parece não combinar muito bem com a ideia de uma cultura de direitos do trabalho corporativa, segmentada e particularista, bem como de um quadro estável e monolítico de cidadania regulada. Nas palavras de Cardoso,

A cidadania regulada, nesse sentido, converteu-se na forma institucional da luta de classes entre nós (...) Isso quer dizer, ademais, que se os direitos sociais e do trabalho (e os serviços de saúde e educação) precisavam ganhar facticidade por meio da luta regulada da luta de classes, então a cidadania regulada precisou ser conquistada pelos candidatos a ela, e isso tanto individual quanto coletivamente $(2010,223)$. A consciência de classes dos trabalhadores brasileiros foi, por muito tempo, a consciência dos direitos a seus direitos, cuja efetividade esteve sempre em processo..." $(2010,239)$.

\section{E acrescenta:}

Mesmo que, para boa parte dos brasileiros, o mundo dos direitos construído ao longo da Era Vargas tenha permanecido uma promessa (...) do ponto de vista que interessa ao argumento aqui defendido, o que importa é que uma vez instituída a legislação social tornou-se objeto real de aspiração das massas despossuídas de recursos e direitos simplesmente porque foi apresentada como, justamente um conjunto de direitos e não como privilégios (Cardoso 2010, 237).

Por sua vez, os historiadores tem procurado mostrar que a perspectiva de reinvenção do trabalhismo varguista e a recorrente "ameaça de ruptura", isto é, de avançar além da outorga getulista e da cidadania regulada sempre se colocou no horizonte de possibilidades da luta dos 
trabalhadores, em que pese o "propósito da tutela" e a pretensão de conformar um operário “restrito e regulado" por parte do poder (Negro 2003, 10). Como assinala Negro,

Vargas não deu a cidadania aos trabalhadores. A gosto seu, ele a reconheceu e integrou na República. Agradecidos os agraciados não renunciaram ao conflito. Mais ainda, não se mantiveram dentro das prescrições da cidadania regulada e forçaram sua ampliação, tanto a partir de quem estava incluído, quanto a partir de quem estava excluído (2002, 280, grifo meu).

Com efeito, diversos são os trabalhos que têm procurado apresentar um quadro mais sofisticado e nuançado do processo de constituição de uma cultura de direitos do trabalho no Brasil desde os ditos anos populistas de 1930 a 1964, questionando as "interpretações que, via de regra, realçam exclusivamente a capacidade do Estado de impor suas mensagens e projetos de controle social", na perspectiva da colaboração de classes. Por conseguinte, se propondo a problematizar determinado "modo de interpretação da realidade, aferrado a certos cânones conceituais populismo, paternalismo, personalismo, 'marca' autoritária - que sobreleva o papel protagonista do Estado, ativo e poderoso, diante de uma classe trabalhadora passiva, objeto de cooptação desse Estado" (Reis 2007, 29-30). Ao inverso, conforme salienta Gomes, o que tais estudos têm observado é uma classe trabalhadora que desde sempre e para além de importantes e violentos constrangimentos, se apresenta como um "sujeito que realiza escolhas segundo o horizonte de um campo de possibilidades" (2001, 46).

De modo semelhante, em relação ao corporativismo brasileiro, trabalhos recentes, como os de Larissa Correa, têm posto em questão a ideia de um sistema de regulamentação corporativista moldado por "aspectos monolíticos e estereotipados", observando certo "caráter flexível” nele. Como salienta a autora, "não se trata aqui obviamente de elaborar uma defesa do corporativismo, mas de apontar para o caráter flexível desse sistema (...) e para os seus possíveis e diferentes significados e reapropriações feitas pelos trabalhadores (2016a, 226-227). Nesse sentido, acrescenta Correa, cumpre "analisar os sistemas de regulamentação trabalhista [leia-se corporativismo] a partir da combinação de outros fatores, como as possibilidades de organização da classe trabalhadora e do regime político em que esses sistemas atuam ou se desenvolveram historicamente" (Correa 2016a, 224-227). Sendo assim, como salienta Lobo, entre as expectativas dos formuladores e o uso efetivo dos trabalhadores seja da legislação trabalhista ou da estrutura sindical corporativa,

alguns estudiosos tem constatado que aquilo que foi prescrito não teve expressão real, tendo em vista, entre outros fatores, que a componente de controle estatal sobre as organizações sindicais foi mitigada entre 1945 e 1964, num ambiente de crescente efervescência social, a despeito da permanência da estrutura sindical erigida no Estado Novo" (Lobo 2019, 117).

Assim, embora criado desde cima, através de "procedimentos autoritários por parte do Estado" com o objetivo mais de "controle dos trabalhadores" - e em que pese sua "elevada 
capacidade de sobrevivência e adaptação" ao longo do tempo - tal "corporativismo à brasileira" (Lobo 2016, 544-546), de maneira geral, não impediu que os trabalhadores, nas diversas conjunturas em que ele se atualizou, forjassem uma "consciência de classe" e uma "cultura de direitos" de modo a ultrapassar "os limites do espaço da fábrica e das relações empregadoempregador" (Correa 2016b, 522).

Enfim, o que esses estudiosos têm apontado é que tanto o arranjo corporativista como a cidadania regulada, apesar de suas intenções de segmentação e controle social, foi desde sempre, evidentemente variando de acordo com o conjunto de possiblidades e constrangimentos colocados pelas diferentes conjunturas, um espaço aberto ao conflito envolvendo tanto a legislação trabalhista, quanto a justiça do trabalho, as instituições previdenciárias e a própria estrutura sindical. Ainda que atravessado por relações em boa medida desiguais em termos de recursos de poder, possibilitou aos trabalhadores a formação, bem ou mal, de uma cultura política de direitos, "gestada [sobretudo] durante o período democrático e identificada fundamentalmente por meio da instrumentalização do código trabalhista [e] do aprendizado de uma linguagem de direitos reapropriada pela classe trabalhadora" (Corrêa 2016b, 505).

Por que é importante dizer isso? Porque me parece que vale a pena pensar um pouco além de uma certa tradição do pensamento social brasileiro que condena de antemão nossa cultura de direitos diante de outras experiências sociais e de cidadania, frequentemente identificadas como modelos ótimos. Ou seja, aqui tudo teria sido marcado pela incompletude, pela falta. Os historiadores têm identificado tal modo de leitura como paradigma da ausência (Chalhoub e Silva 2009; Nascimento 2016.). Se tivemos uma cultura de direitos ela foi segmentada e corporativa nunca uma cultura de solidariedade de classe entre os trabalhadores, sobretudo entre incluídos e excluídos na cidadania regulada, sendo que tal cultura de direitos teria sido a principal responsável pela impossibilidade de uma extensão efetiva da cidadania, uma cidadania ampla como nos outros países, notadamente na Europa e nos EUA. No entanto, na própria Europa ocidental, no início dos sistemas de proteção social no começo do século XX, nada se processou como acesso universal e em grande medida estavam relacionadas a capacidade de contribuição dos sujeitos. O conceito ampliado de proteção social de escopo universal, baseado na ideia de seguridade social, só se afirmou, e mesmo assim com diferenças de país a país, no pós segunda guerra (Monnerat e Senna 2007; Pereira 2008; Kerstenetzky 2012)

Observemos de modo breve aqui alguns exemplos que servem, se não de contraponto a esta perspectiva, pelo menos como evidências que problematizam as leituras que identificam a política social e a cultura de direitos no Brasil como eventos monolíticos e absolutamente estabelecido desde a Era Vargas. Começo pela discussão ocorrida em torno da criação do Instituto 
dos Serviços Sociais do Brasil (ISSB) levada a efeito no último ano do primeiro governo Vargas (1945). Em consonância com certo clima internacional favorável a reformas estabelecidas a partir do princípio de "solidariedade social", o objetivo era avançar em termos da universalização e ampliação dos benefícios e serviços, inclusive da assistência médica, bem como promover a unificação administrativa e financeira da previdência, segundo o princípio "de cada um de acordo com seus meios, e para cada um de acordo com sua necessidade”(Malloy 1986, 91-92). O plano do ISSB envolvia, de acordo com Malloy, um "radical e grandioso esquema de reformas", organizado em "três dimensões funcionais que dariam uma cobertura do "berço ao túmulo" (1986, 92). O decreto que o estabelecia, de acordo com Cohn, "estipulava (...) a universalização da previdência e atribuía à assistência médica importância equivalente aos benefícios" $(1980,10)$. Na exposição de motivos da comissão organizadora do ISSB era dito que ele deveria "alcançar, em seu amparo, todos os habitantes do território nacional", representado "um marco na história da previdência social brasileira", sendo capaz de influenciar "toda e qualquer tentativa de racionalização e mesmo unificação dos anos posteriores" (Cohn 1980, 11, grifo meu). Nesse sentido, Hochman considera que a proposta de criação do ISSB significava "o desmantelamento de toda uma estrutura de diferenciação que prevalecia no sistema previdenciário", expressando "um corte radical com o modelo então vigente no Brasil e contemporânea às propostas debatidas no exterior" (1988, 86), o que, convenhamos, não é pouca coisa. E logo adiante o autor acrescenta:

A organização do ISSB, com a reestruturação da previdência social e sua ampliação incluindo a assistência social, era vista como necessária ao progresso do país e, dentro dessa finalidade, o projeto deixa 'de lado classificações de grupos profissionais distintos, preceituando, antes, a congregação de todos os nacionais ou estrangeiros no país, que aufiram rendimentos (...) como contribuintes do regime de previdência e assistência social” (...). Dentro do 'espírito da época', o projeto do ISSB traz consigo além da proposta da unificação dos Institutos e das Caixas, a universalização dos benefícios, a uniformização dos regimes de contribuição e a inclusão da assistência médica como direito dos segurados. Isso implicaria uma reformulação do conceito de cidadania, até então regulada pelo Estado e estratificada por categorias profissionais, para uma concepção de 'congregação de todos os nacionais e estrangeiros radicados no Brasil'. Enfim, a formulação clássica de cidadania definida como um 'status concedido àqueles que são membros integrais de uma comunidade' $(1988,88)$.

Como é possível observar a proposta era bastante ousada, porquanto rompia em grande medida com os fundamentos da propalada cidadania regulada e pouco ficava aquém do que se advogava na Europa de então em termos de política social. De qualquer forma, embora estabelecido pelo decreto-lei no 7526 de 07 de maio de 1945, o ISSB acabou não vingando, em função de resistências diversas. Das companhias de seguro certamente já que o plano "de maneira absolutamente revolucionária estatizava o seguro contra acidentes de trabalho custeado através de contribuições especiais dos empregadores" (Hochman 2015, 5). Outra fonte de oposição veio dos setores sindicais já que, segundo Malloy (1986, 93-94), estes receavam perder o controle sobre as instituições de previdência, o que de certo modo reforça o argumento corporativista e anti- 
solidarista por parte dos trabalhadores organizados. No entanto, tendo em vista a ousadia da proposta que, como indica Hochman, em larga medida procurava romper com "a estrutura de diferenciação que prevalecia no sistema previdenciário" e com o próprio "conceito de cidadania, até então regulada pelo Estado e estratificada por categorias profissionais", tal fato não deixa também de ser revelador de como o corporativismo varguista e o fundamento da cidadania regulada não eram princípios monolíticos, apresentavam fissuras e certa flexibilidade de propósitos desde o seu nascedouro, com espaço inclusive para absorver formulações que apontavam, ainda nos anos 1940, para perspectivas bem mais universalistas em termos de direitos sociais.

Outro exemplo que pode ser citado, é a tentativa, em 1954, de implantação de uma Lei Orgânica da previdência, que se arrastava desde 1947 (após o fracasso do ISSB). Depois de muita discussão e falta de consenso no legislativo sobre a sua implantação, Vargas apela ao seu poder e emite um decreto, de $\mathrm{n}^{\circ}$ 35.448, que visava reformar o sistema previdenciário (Malloy 1986, 102). De acordo com Malloy, tal decreto "ligava-se explicitamente às ideias gerais do decreto gorado de 1945, que criava o ISSB", embora considere que o que se pretendia era uma "pálida imitação do plano de 1945", porquanto "não abrangia o conceito de unificação" e mantinha o "sistema de recurso múltiplos". No entanto, tinha a pretensão de "englobar todas as classes, alcançando inclusive os trabalhadores rurais, os domésticos e os autônomos", que poderiam "integrar-se ao sistema voluntariamente desde que pagassem as contribuições do empregado e do empregador" (1986, 102, grifo meu). Com o suicídio de Vargas em 1954 mais uma vez tal reforma não vingou, sendo o referido decreto revogado por Café Filho, "sob a alegação de que constituía um exercício inconstitucional" $(1986,102) .{ }^{11}$ De qualquer forma, embora frustrado, o que se observa novamente aqui é certa intenção de ampliação do acesso à proteção social, para além dos limites estabelecidos pelo princípio da cidadania regulada ou da lógica do "só quem tem oficio tem benefício".

Vejamos também como mais uma importante evidência, a direção que o sistema previdenciário toma com a aprovação da Lei Orgânica da Previdência social (LOPS) de 1960, "após 13 anos de luta legislativa” (Malloy 1986, 109), que uniformizava tanto as contribuições quanto os serviços e benefícios, conferindo a eles a "mesma importância na definição das finalidades da previdência social" (Cohn 1980, 13). Ademais, estabelecia uma direção efetivamente colegiada nos institutos, importante bandeira dos trabalhadores, embora mantivesse a estrutura fragmentada do

\footnotetext{
${ }^{11}$ Como sabemos tais trabalhadores só puderem se incorporar à previdência social após a unificação ocorrida em 1966 já no regime militar, com a inclusão dos trabalhadores rurais em 1971 (Prorural/Funrural), dos empregados domésticos em 1972 (lei 5.899) e dos trabalhadores autônomos em 1973 (lei 5890).
} 
sistema (Hochman, Maio, e Lima 1989, 72; Vianna 2000, 159) ${ }^{12}$. Segundo o próprio Santos, formulador intelectual do conceito de cidadania regulada, a LOPS seria expressão inicial de um processo que buscava "minar" o princípio de uma cidadania caracterizada pela inserção dos indivíduos em alguma ocupação reconhecida e definida em lei (1979, 79); ou, como quer Vianna, a "única mudança infringida a esta arquitetura organizacional", se referindo, no caso, aos "padrões desiguais de proteção" a "clientela hierarquizada" e as "mediações corporativas" do sistema previdenciário que, segundo a autora, tinham vigência (2000, 141). Por sua vez, de acordo com Kerstenetzky, a LOPS, embora "não tão radical quanto o ISSB”, refletiria uma importante mudança "na direção da universalização da seguridade", através da "uniformização do sistema" e do estabelecimento de "um conjunto de 18 benefícios e serviços" $(2012,197)$.

Oliveira e Teixeira $(1986,166)$, consideram que a promulgação da LOPS significou "um marco [na] derrota final do modelo contencionista, ao estender para o conjunto dos segurados da Previdência, um plano extremamente amplo de benefícios e serviços”. Se proporia inclusive a integrar no sistema, segundo Malloy $(1976,18)$, "grupos novos, como os profissionais autônomos e liberais", embora não os empregados em serviços domésticos e o enorme contingente de trabalhadores rurais que continuariam na condição de pré-cidadãos aspirantes à "inclusão na chave dos direitos sociais" (Cardoso 2010, 239). Nesse sentido, é possível sugerir, acompanhando a provocadora análise de Cardoso, que a exclusão "pod [ia] ser temporária, isto é, a cidadania aparec[ia], para esses pré-cidadãos, como possibilidade" $(2010,219)^{13}$. De fato, no caso dos que laboravam no campo, tal possibilidade se apresentou com a promulgação do Estatuto do Trabalhador Rural em 1963, que estendia "direitos trabalhistas e previdenciários aos trabalhadores rurais fora da lógica contributiva", embora, ao fim e ao cabo, com pouca efetividade em termos concretos, tendo em vista o golpe civil militar que depôs o governo Goulart em 1964 (Kerstenetzky 2012, 198) ${ }^{14}$.

Como quer que seja, com todos os limites observados (exclusão dos rurais principalmente) o que parece ficar claro aqui é que entre os anos 1945-1964 se verificou um processo que pretendia avançar, embora em grande medida travado na prática, no sentido da universalização da previdência e da ideia mais ampla de seguridade social ${ }^{15}$.

\footnotetext{
12 Como salienta Hochman, o apoio dos bancários, "historicamente tidos como opositores a qualquer forma de uniformização”, à LOPS “deveu-se fundamentalmente à inclusão nessa lei da chamada direção colegiada, isto é, a presidência seria exercida por representantes da União, dos empregadores e dos trabalhadores em rodízio” (1992, 121). ${ }^{13}$ Conforme aponta Cardoso, a condição de pré-cidadãos “denota, a um só tempo, exclusão do mundo dos direitos e existência de mecanismos pelos quais, em algum momento, os pré-cidadãos podem ser incluídos, tornando-se membros plenos da comunidade de direitos" (2010, 219).

${ }_{14}$ Para tanto seria criado um Fundo de Assistência e Previdência do Trabalhador Rural formado com o recolhimento de 1\% da produção agropecuária.

15 Segundo Vianna, "seguridade social é um termo cujo uso se tornou corrente a partir dos anos 40, no mundo desenvolvido e particularmente na Europa, para exprimir a ideia de superação do conceito de seguro social no que diz
} 
Após a implantação da LOPS, quem dirige o Departamento Nacional de Previdência Social (DNPS), “órgão de máxima autoridade nos assuntos previdenciários” (Cordeiro 1984, 39), é o sindicalista Dante Pellacani (cassado pelo movimento militar de 1964), ligado ao PTB, que tem sua atuação marcada pela preocupação com os serviços de assistência médica, o que permite caracterizar esse período, segundo Cordeiro, como marcado pela tentativa de se buscar "uma solução conciliatória dos vários modelos [de prestação médica] existentes, mas que salvaguardasse essa prestação da privatização generalizada e privilegiasse o quanto possivel os serviços próprios" (1984, 43, grifo meu). No entanto, o que em geral se diz é que os trabalhadores organizados, os sindicalistas e sindicatos do período, se viram fortemente atraídos pela oferta do ascendente mercado privado de saúde, tendo em vista que "a forma de organização da assistência médica pelos antigos IAPs teria vinculado desde cedo os trabalhadores urbanos à prestação privada de serviços de saúde, o que também os teria levado a dar sustentação à saúde privada e não à pública” (Rodrigues 2014, 47). Postura que ganharia enorme impulso com a unificação dos institutos no INPS durante o regime militar (Menicucci 2007).

Cohn (1980, 13), por exemplo, considera que a "expansão da assistência médica via privatização", típica da unificação previdenciária pós 1964, já se encontrava delineada na LOPS de 1960. Posição que contrasta com a de Cordeiro que entende que neste momento os "convênios com sindicatos e outras entidades para prestação de assistência médica pelos IAPs (...) diferiam da forma como foram implementados após 1964" $(1984,42)$. Com efeito, de acordo com o autor, os ditos convênios "eram definidos como uma forma alternativa de prestação de atendimento para as localidades onde não havia conveniência em manter serviços próprios pelos IAPs; a preferência deveria sempre recair nas entidades sindicais, depois em empresas públicas e, finalmente nas instituições privadas $(1984,42)$.

Oliveira e Teixeira, por sua vez, consideram o período que vai de "1945 à unificação dos institutos em 1966”, como “correspondendo a um verdadeiro ‘boom’ de expansão do setor próprio de assistência médica previdenciária, tendo surgido aí pelo menos $3 / 4$ dos atuais hospitais de nossa previdência social". E logo em seguida acrescentam: "A prática de comprar serviços médicos e hospitalares a terceiros era, além disso, mantida. Agora, contudo, ao contrário do que ocorria no período anterior [até 1945], essa atitude era definida como meramente provisória" (Oliveira e Teixeira 1985, 184-185). Como dito na mensagem presidencial de 1950, se referindo à situação do

respeito à garantia de segurança das pessoas em situações adversas. Significa que a sociedade se solidariza com o indivíduo quando o mercado o coloca em dificuldades. Ou seja, significa que o risco a que qualquer um, em princípio, está sujeito - de não conseguir prover seu próprio sustento e cair na miséria - deixa de ser problema meramente individual e passa a constituir uma responsabilidade social, pública” (2007, 173). 
IAPTEC, “nos locais em que a massa segurada, pela sua diluição, ainda não permite a instalação de ambulatórios, o instituto manteve o sistema de credenciar ou contratar médicos, dentistas, serviços de enfermagem e hospitais" (Apud Oliveira e Teixeira 1985, 185).De modo semelhante, na mensagem presidencial de 1949, nesse caso tratando do IPASE, se afirmava que o referido instituto tomara "a decisão, para atender aos seus segurados e beneficiários, de designar e credenciar ou contratar profissionais que, trabalhando em consultórios próprios, prestarão assistência médica até que seja instalado o ambulatório do instituto" (Apud Oliveira e Teixeira 1985, 185). Como se pode notar, parece que a preferência recaia na utilização e ampliação de serviços próprios e só excepcionalmente - de maneira "provisória", ou "onde não havia conveniência" ou ainda "pela diluição" da massa segurada - pela contratação de serviços privados ${ }^{16}$.

Enfim, alguns exemplos que servem para mostrar que as coisas não estavam assim tão definidas e estabelecidas, envolviam disputas e apresentavam contradições desde os seus momentos iniciais e que portanto a cidadania regulada, a segmentação e seletividade de acesso aos serviços de saúde e aos direitos e proteção social em geral, não constituíam uma causa sem fissuras do projeto de poder e controle da cultura política trabalhista e corporativista brasileira.

\section{Considerações finais}

Nos seus importantes estudos sobre a trajetória da cidadania no Brasil, José Murilo de Carvalho assevera que por ter fugido ao modelo clássico, com maior ênfase nos direitos sociais, a cultura de direitos de cidadania no Brasil teria sido corrompida, construindo ou o aborto da estadania ou do corporativismo. Palavras precisas dele: "No Brasil [...] quando a virtude privada estabelece contato com o Estado, gera o aborto da estadania e do clientelismo, quando a virtude do Estado se comunica com a sociedade, gera o aborto do corporativismo. Nos dois casos [...], não há virtude, não há cidadania participante” (2000, 123). Como se vê, estamos bem mal aqui.

No campo da saúde (que é o que meu estudo trata),como vimos, é quase um consenso que nosso modelo de cidadania vindo dos anos 1930, estabelece um certo tipo de enquadramento da nossa cultura de direitos que interfere de modo intenso "nos desdobramentos políticoinstitucionais ocorridos nas décadas seguintes" (Fonseca 2007, 57), ou seja, no que veio a se constituir como proteção social - saúde incluída - desde esse período até, em grande medida, os dias atuais, inviabilizando ou ao menos estabelecendo sérios constrangimentos à perspectiva de direito à saúde investida de um sentido igualitário e universal. A reforma sanitária brasileira que deu

${ }^{16}$ Como apontam Oliveira e Teixeira, o IAPI, "velho bastião das tendências contencionistas e que até recentemente resistira a prestar assistência médica sob qualquer forma a seus segurados” destoava desta orientação $(1985,185-186)$. 
origem ao SUS no final dos anos 1970 e anos 1980, por exemplo, quando se propõe a instituir a saúde como um direito de todos e dever do Estado, tal como descrito na Constituição de 1988, contraria a longa tradição segmentada e supostamente corrompida de direitos no Brasil, se pondo na contramão de algo até então impensável no país - a ideia mesmo da saúde como um direito, e por esta razão, ao fim e ao cabo, acaba apenas por repor, em novos termos, antigos arranjos repaginados de exclusão e segmentação no acesso à saúde ${ }^{17}$. Ou seja, parece que certa tradição corporativa vinda dos anos 30, instaladora de uma cultura de direitos excludente e segmentada, marcada pela diferenciação e pela ausência de solidariedade, espécie de moléstia originária, se imporia como modelo monolítico de relação entre Estado e sociedade, estabelecendo, para além do modo como afeta o conjunto daqueles que vivem do trabalho, uma espécie de fosso intransponível na relação entre pobres (excluídos) e trabalhadores (incluídos) ${ }^{18}$. Como aponta Ronaldo Santos,

se ao analisar o pós 64 muitos autores identificam uma inflexão privatizante que não constava no projeto estatal varguista, o que permaneceria inalterado para a análise de todo o período, seria a herança segmentada de acesso a direitos - manifestações exclusivas e insistentes desse regime prémoderno e antidemocratizante dos pós 30 (2014, 108-109).

Parafraseando o historiador Luigi Negro $(2004,21)$, na sua crítica irônica àqueles que aprisionam nossa história à maldição de um "ente chamado herança colonial” ibérica ("Ibéricos, logo imperfeitos - ontem, hoje e amanhã”), podemos dizer, igualmente em tom de crítica aos que amaldiçoam nossa pertença corporativa: Corporativistas, logo imperfeitos - ontem, hoje e amanhä! Com efeito, vale observar como boa parte dos estudos que tratam do acesso ao sistema de previdência social e à assistência à saúde no Brasil - que eu inclusive tenho me valido para sugerir outras possibilidades de interpretação - responsabilizam a cultura política trabalhista e seus modelos excludente de cidadania regulada e corporativismo estabelecidos no pós 1930, pelos padrões desiguais, segmentados e hierarquizados, de acesso a um tal sistema de proteção social. Para tanto, aderem, com maior ou menos entusiasmo, a perspectiva que só vê arranjos e planos orquestrados desde cima, quando não por lógicas de ação atravessadas pela busca de privilégios e ganhos exclusivos por parte dos trabalhadores, nunca de solidariedade.

Segundo Vianna (2000, 141-142), por exemplo, uma das mais importantes estudiosas do tema, a pressão que os diferentes grupos sociais faziam para que suas demandas por benefícios

\footnotetext{
${ }^{17}$ Com a particularidade de que agora tal acesso diferenciado, como vimos, estaria vinculado "ao contrato de trabalho e não [mais] à categoria profissional como ocorria antes da unificação dos IAPS” (Meninucci 2007, 87).

${ }^{18}$ Como os estudos recentes de historiadores do trabalho tem procurado mostrar parece que não foi bem assim. Como sugere Luigi Negro, embora construída desde cima, a cultura política trabalhista não teria cavado "um fosso entre excluídos e incluídos". Pelo contrario, teria ido "ao encontro de expectativas e iniciativas por justiça social (...) ao figurar no caminho de movimentos e iniciativas que requisita[va]m sua contemplação pelas leis do trabalho, ou que usa[va]m precedentes para melhorar sua posição de barganha, inclusive da parte dos trabalhadores rurais (2004, 22, grifo meu).
} 
fossem atendidas, estimulava certo tipo de competição entre os institutos com vistas antes a "conquista de privilégios" e "a conseguir um esquema de proteção melhor que os demais" do que qualquer intenção mais solidaria ou de consciência coletiva de classe. O resultado disso apontaria para a instalação de "padrões desiguais de proteção e uma clientela hierarquizada, prisioneira das mediações corporativas" incapaz de uma "atuação reivindicatória mais consistente". Nos termos da autora, tal situação teria se mantido e até se aguçado por conta do populismo "no interregno democrático que se estendeu da queda de Vargas, em 1945, ao golpe militar de 1964”, tendo em vista "que a expansão dos benefícios proporcionados por cada Instituto ocorria heterogeneamente na esteira de pressões e acordos políticos particularizados pelo corporativismo sindical”"

Por sua vez, de acordo com Rodrigues $(2018,47){ }^{19}$,“o formato corporativo das políticas sociais" dos anos 1930 até a criação do INPS, teria afetado qualquer possibilidade de uma "ideologia de classe e de solidariedade entre os trabalhadores", instituindo antes segmentação e privilégio, do que uma "base de sustentação política para um sistema universal de saúde", além de estabelecer vínculos dos trabalhadores urbanos com “a prestação privada de serviços de saúde" e muito pouco com a pública.

No entanto, se de fato foi assim que tudo se processou, uma pergunta inquietante precisa ser feita: como teria sido possível romper com estruturas de domínio e poder, bem como de arranjos sociais, tão arraigados, constrangedores e duradouros - corporativismos, cidadanias reguladas, clientelismos, paternalismos, patrimonialismos, populismos, enfim, nossa ampla coleção de moléstias (Barboza Filho 2010, 41) - de modo a estabelecer a ideia absolutamente inusitada da saúde como um direito de todos e dever do Estado, tal como estabelecido na Constituição de 1988?Processo histórico e político que, convenhamos, não significou pouca coisa! Com efeito, como mostra Rocha $(2019,178)$, se considerarmos que a ideia propriamente dita de direito à saúde não se refere apenas ao usufruto de "serviços médicos propriamente ditos" e sim a um "direito amplo relacionado à garantia de acesso a bens e serviços” determinantes para uma dada condição saudável ${ }^{20}$, tal processo só se fez presente, como garantia constitucional, em meados do século XX e em alguns poucos países ${ }^{21}$, tendo em vista que o que se tinha antes eram normas que a defendiam

\footnotetext{
$19 \mathrm{O}$ autor se vale de algumas pistas inferidas da literatura mais geral que trata da reforma sanitária oriunda, segundo ele, tanto "da saúde coletiva, quanto das áreas da história e da ciência política” (2018, 47). Importante salientar, entretanto, que Rodrigues reconhece que tais indicações ainda necessitam de estudos mais conclusivos.

20 Aquilo que os especialistas da saúde, sanitaristas e militantes da saúde coletiva, identificam como "concepção ampliada de saúde" que considera, para além do acesso a serviços e equipamentos de saúde, também os chamados "determinantes sociais da saúde": saneamento, educação, assistência social, moradia, trabalho, etc.

${ }^{21}$ Aparece dessa forma no artigo 21 da Declaração Universal dos Direitos Humanos de 1948 que assevera no seu artigo 25: “todo ser humano tem direito a um padrão de vida capaz de assegurar a si e à sua família saúde, bem estar, inclusive alimentação, vestuário, habitação, cuidados médicos e os serviços sociais indispensáveis e direito à segurança em caso
} 
como resultado do avanço econômico-social de um país. Nesse caso, a introdução do SUS na Constituição de 1988 não parece ter destoado tanto do que se passou no cenário internacional. O mesmo se dá em relação à implantação da perspectiva mais efetiva da seguridade social que, como vimos, só se institui a partir dos anos pós segunda guerra mundial.

Nesse sentido é que talvez seja interessante acompanhar as novas perspectivas abertas pelos estudos mais recentes de historiadores e sociólogos sobre os mundos do trabalho, suas tensões e contradições (alguns deles apresentados aqui), estudos que tem questionado boa parte das interpretações consagradas sobre o dito sindicalismo corporativista e, através deles ou em dialogo com eles, refazer algumas perguntas inquietantes que nos ajudem a problematizar, como eu tentei fazer neste texto, a ideia de uma construção de cidadania tão arraigada e corrompida que quando muda apenas reitera velhas e carcomidas estruturas de poder, dominação, controle e conformação social. Vale dizer, perguntas que em alguma medida matizem a ideia de uma cultura de direitos e um sistema de proteção social atravessados por uma monolítica e irresistível estratificação, segmentação, diferenciação e seletividade. Quem sabe por esse caminho, a ideia de seguridade social e o estabelecimento do SUS na Constituição de 1988, possam ser mais bem compreendidos e, por conseguinte, vistos como arranjos sociais não tão inusitados ou em completo desalinho tanto com relação a nossa própria história quanto no que tange a padrões internacionais.

\section{Referências bibliográficas}

Barboza Filho, Rubem. "A modernização brasileira e o nosso pensamento político". Perspectivas, São Paulo, 37, jan./jun (2010): 15-64.

Braga, Jose Carlos de Souza, e Paula, Sergio Goes de. Saúde e previdência: estudos de política social. São Paulo: Cebes/Hucitec, 1981.

Cardoso, Adalberto Moreira. A Construção da sociedade do trabalho no Brasil, Rio de janeiro: FGV, 2010.

Carvalho, José Murilo de. "A cidadania na encruzilhada”. Em Pensar a república, org. Bignotto, Newton, 105-130, Belo Horizonte: UFMG, 2000.

Chalhoub, Sidney, e Silva, Fernando Teixeira. "Sujeitos no imaginário acadêmico. Escravos e trabalhadores na historiografia brasileira desde os anos 1980". Cadernos AEL, 14, n. 26 (2009): 1346.

Cordeiro, Hésio. As empresas médicas, Rio de Janeiro: Graal, 1984.

Correa, Larissa. "Corporativismo e regulamentação do trabalho no Brasil: um debate entre especialistas brasileiros e norte-americanos na década de 1960", Sociologia Antropologia, 6, n. 1 (2016a): 209 -234. https://doi.org/10.1590/2238-38752016v619

de desemprego, doença, invalidez, viuvez, velhice ou outros casos de perda dos meios de subsistência em circunstâncias fora de seu controle" (Apud Rocha 2019, 179). 
Correa, Larissa. "O corporativismo dos trabalhadores: leis e direitos na Justiça do Trabalho entre os regimes democrático e ditatorial militar no Brasil (1953-1978)", 42, n. 2 (2016b): 500-526. https:// doi.org/10.15448/1980-864X.2016.2.22494

Costa, Nilson do Rosário. Políticas Públicas, Direitos e interesses: Reforma Sanitária e Organização Sindical no Brasil. Em Política de Saúde: o Público e o Privado, org. Benschultz, Catalina, 345-362. Rio de Janeiro: Fiocruz, 1996.

Fonseca, Cristina Oliveira M. Saúde no Governo Vargas (1930-1945): dualidade institucional de um bem público. Rio de Janeiro: Ed. Fiocruz, 2007.

Fonseca, Cristina. A história das políticas de saúde no Brasil (1889-1945): interpretações e trajetórias, Em História da saúde no Brasil, orgs. Teixeira, Luiz Antonio, Hochman, Gilberto, Pimenta, e Tânia Salgado, 403-429. São Paulo: Hucitec, 2018.

Gomes, Angela de C. A Invenção do Trabalhismo. São Paulo, Rio de Janeiro: Vértice/Iuperj, 1988.

Gomes, Angela de C. "O Populismo e as ciências sociais no Brasil: notas sobre a trajetória de um conceito". Em O Populismo e sua História: debate e crítica, org. Ferreira, Jorge, 17-57. Rio de Janeiro: Civilização Brasileira, 2001.

Fleury, Sonia. "Assistência médica previdenciária - evolução e crise de uma política social”. Em Saúde em Debate - fundamentos da Reforma sanitária, orgs. Bahia, Lígia, Amarante, Paulo, e Fleury, Sonia, 87-102. Rio de Janeiro: Cebes, 2007.

Hochman, Gilberto. 2006. "Previdência e assistência social nos Anuários Estatísticos do Brasil". https://biblioteca.ibge.gov.br/visualizacao/livros/liv2052.pdf.

Hochman, Gilberto. Reformas, instituições e políticas de saúde no Brasil (1930-1945), Educar em revista, n.25 (2005): 127-141. https://doi.org/10.1590/0104-4060.370

Hochman, Gilberto. A saúde publica em tempos de Capanema: continuidade e inovações. Em Constelação Capanema: intelectuais e políticas, org. Bomeny, Helena, 127-151. Rio de Janeiro: Editora FGV, 2001.

Hochman, Gilberto. Duas Gêneses, Duas Histórias na Previdência Social Brasileira: O Instituto dos Industriários e o Instituto dos Bancários. Cadernos da Casa de Oswaldo Cruz, Rio de Janeiro, 1, n.2 (1992): 113-123.

Hochman, Gilberto. Aprendizado e Difusão na Constituição de Políticas: A Previdência social e seus técnicos, Revista Brasileira de Ciências Sociais, 3, n. 7 (1988): 84-98.

Hochman, Gilberto, e Fonseca Cristina. "O que há de novo? Políticas de saúde pública e Previdência (1937-1945)”. Em Repensando o Estado Novo, org. Pandolfi, Dulce,73-93. Rio de Janeiro: FGV, 1999.

Hochman, Gilberto, Lima, Nísia Trindade, e Maio, Marcos Chor. “Assistência Médica na Previdência Social Brasileira: questões da Literatura". Cadernos da Casa de Oswaldo Cruæ, 1, n.1 (1989): 62-76.

Kerstenetzky, Célia. O Estado do Bem-Estar Social na Idade da Raz̧ão. Rio de Janeiro: Elselvier, 2012.

Lima, Nísia Trindade, Fonseca, Cristina Oliveira, e Hochman, Gilberto. "A saúde na construção do Estado nacional no Brasil: reforma sanitária em perspectiva histórica". Em Saúde e democracia: bistória e perspectivas do SUS, orgs. Lima, Nísia Trindade, et al., 27-58. Rio de Janeiro: Editora Fiocruz, 2005.

Lobo, Valéria Marques. Corporativismo à Brasileira: entre o autoritarismo e a democracia, Estudos Ibero-americanos, 42, n. 2(2016): 527-552. https://doi.org/10.15448/1980-864X.2016.2.22514 
Lobo, Valéria Marques. Democracia e Justiça: Tribunais do Trabalho no Estado Novo. Em O que há de novo sobre o Estado Novo? Autoritarismo e democracia, orgs. Freire, Américo, Martinho, Francisco Carlos P, e Vannucchi, Marco Aurélio, 111-134. Rio de Janeiro: FGV, 2019.

Malloy, James. Política de Previdência Social no Brasil, Rio de Janeiro: Edições Graal, 1986.

Malloy, James. "Política de bem-estar social no Brasil: histórico, conceitos, problemas". Revista de Administração Pública, 10, n. 2 (1976): 5-29.

Menicucci, Telma Maria Gonçalves. Público e Privado na Política de Assistência à saúde no Brasil: atores, processos e trajetória. Rio de janeiro: Editora Fiocruz, 2007.

https://doi.org/10.7476/9788575413562

Monnerat, Giselle Lavinas, e Senna, Mônica de Castro M. "A seguridade social Brasileira: dilemas e desafios". Em Sociedade, estado e direito à saúde, orgs. Morosini, Márcia Valéria Guimarães Cardoso, e Reis, José Roberto Franco, 103-154.Rio de Janeiro: EPSJV/Fiocruz, 2007.

Nascimento, Álvaro Pereira. "Trabalhadores negros e o "paradigma da ausência": contribuições à História Social do Trabalho no Brasil”. Estudos históricos. 29, n.59 (2016): 607-626. https://doi.org/10.1590/s2178-14942016000300003

Negro, Antonio Luigi. "Paternalismo, Populismo e História Social”. Cadernos AEL, 11, n. 20/21 (2004): 11-38.

Negro, Antonio Luigi. "Ignorantes, Sujos e Grosseiros: una Reinvenção da História do Trabalhismo". Trajetos, 2, n. 4 (2003): 9-33.

Negro, Antonio Luigi. "Um PCB é pouco, dois é bom, três é demais. A participação operária na política do pós guerra”. História, 21 (2002): 251-282.

Pereira, Potyara. A. P. Política Social: temas e questões. São Paulo: Cortez, 2008.

Reis, José Roberto Franco. "Cultura de Direitos e Estado: os caminhos (in)certos da cidadania no Brasil”. Em Sociedade, estado e direito à saúde, orgs. Morosini, Márcia Valéria Guimarães Cardoso, e Reis, José Roberto Franco, 15-61. Rio de Janeiro: EPSJV/Fiocruz, 2007.

Reis, José Roberto Franco. "Viver é influenciar": Mário Magalhaes, sanitarismo desenvolvimentista e campo intelectual da saúde pública (1940-1960)". Tempo Social, revista de sociologia da USP, 27, n. 2 (2015): 279-304. https://doi.org/10.1590/0103-20702015213

Rocha, Rudi. "A saúde na Constituição de 1988: trinta anos de SUS e os desafios pela frente". Em A Carta: para entender a Constituição Brasileira, orgs. Meneses Filho, Naercio, e Souza, André Portela, 173-199. São Paulo: Todavia, 2019.

Rodrigues. Paulo Henrique. "Desafios Políticos para a consolidação do Sistema Único de Saúde: uma abordagem histórica". História, Ciência, Saúde - Manguinhos, 21, n. 1 (2014): 37-59. https://doi.org/10.1590/S0104-59702014000100003

Santos, Wanderley Guilherme dos Santos. Cidadania e Justiça. Rio de Janeiro: Campus, 1979.

Santos, Ronaldo Teodoro dos. "O fantasma da classe ausente: as tradições corporativas do sindicalismo e a crise de legitimação do SUS". Tese de Doutoramento, Belo Horizonte, Universidade Federal de Minas Gerais, 2014.

Vianna, Maria Lúcia T. Werneck. A americanização (perversa) da seguridade social no Brasil: estratégia de bem-estar e políticas públicas. Rio de Janeiro: Revan-Ucam-Iuperj, 2000. 
Vianna, Maria Lucia T. Werneck. "O silencioso desmonte da Seguridade Social no Brasil: o papel dos benefícios contributivos". Em Politica social e democracia, orgs. Bravo, Maria Inês, e Pereira, Potyara A. P., 173-196. São Paulo: Cortez / Rio de Janeiro: UERJ, 2007.

Recebido: 22 de fevereiro de 2020

Aprovado: 30 de março de 2020 